\title{
IMPLEMENTASI PERMENPERIN NO. 1 TAHUN 2020 TENTANG RKL RPL RINCI DI KAWASAN INDUSTRI BLESSINDO (STUDI KASUS DI KABUPATEN TANGERANG)
}

\author{
Mico Juli Fikra, Gunawan Djajaputra \\ Universitas Tarumanagara (UNTAR) Jakarta, Indonesia \\ Email: michojulifikra@yahoo.com,gunawand@fh.untar.ac.id
}

\begin{abstract}
Abstrak
Negara Indonesia adalah Negara Hukum, semua aktivitas masyarakat mengacu pada peraturan yang berlaku. Peraturan bersifat dinamis, sehingga akan selalu ada peraturan baru yang akan dibentuk sesuai dengan kebutuhan masyarakat. Salah satu Peraturan baru yang dibuat untuk dibuat untuk mengakomodir penyederhanaan proses perizinan agar tingkat investasi meningkat adalah Peraturan Menteri Perindustrian dan Perdagangan Nomor 1 Tahun 2020 tentang RKL RPL rinci. Tujuan dari penelitian ini adalah untuk mengetahui bagaimana implementasi kebijakan peraturan Menteri Perindustrian dan Perdagangan Nomor 1 Tahun 2020 tentang Penyusunan RKL RPL rinci di kawasan industri Blessindo Kabupaten Tangerang, sebagai salah satu kebijakan yang baru diterapkan oleh Pemerintah Indonesia. Metode penelitian yang digunakan dalam penelitian ini adalah metode pendekatan yuridis empiris, sampel dalam penelitian ini diambil dengan menggunakan teknik nonrandom secara purposive sampling dimana penarikan sampel dilakukan dengan cara mengambil subjek berdasarkan pada tujuan tertentu. Berdasarkan hasil penelitian yang didapatkan dari hasil wawancara dengan masyarakat setempat, didapatkan gambaran bahwa masyarakat belum mengetahui mengenai adanya peraturan Peraturan Menteri Perindustrian dan Perdagangan Nomor 1 Tahun 2020 tentang Penyusunan Rencana Pengelolaan Lingkungan Hidup dan Rencana Pemantauan Lingkungan Hidup Rinci bagi perusahaan industri yang berada atau akan berlokasi di kawasan industri. Kurangnya informasi dan pengetahuan masyarakat mengenai peraturan pemerintah ini akan sangat mempengaruhi persepsi masyarakat terhadap keberadaan suatu kegiatan dan akan menentukan bagaimana masyarakat akan mengambil sikap dan tindakan
\end{abstract}

Kata Kunci: implementasi kebijakan; RKL RPL rinci; kawasan industri

\section{Abstract}

The State of Indonesia is a State of Law, all community activities refer to the prevailing regulations. Regulations are dynamic, so there will always be new regulations that will be formed according to the needs of the community. One of the new regulations made to be made to accommodate the simplification of the licensing process in order to increase investment levels is Regulation of the Minister of Industry and Trade No. 1 of 2020 concerning detailed RPL RKL. The purpose of this research is to find out how to implement the regulation policy of the Minister of 
Industry and Trade No. 1 of 2020 concerning the Preparation of detailed RPL RKL in the Blessindo industrial estate of Tangerang Regency, as one of the new policies implemented by the Government of Indonesia. The research method used in this study is empirical juridical approach method, the sample in this study was taken using non random purposive sampling technique where sampling is done by taking the subject based on a specific purpose. Based on the results of research obtained from interviews with local communities, it is obtained an illustration that the public does not yet know about the regulation of the Minister of Industry and Trade Regulation No. 1 of 2020 concerning the Preparation of Environmental Management Plans and Detailed Environmental Monitoring Plans for industrial companies located or will be located in industrial areas. The lack of information and knowledge of the public about this government regulation will greatly affect the public's perception of the existence of an activity and will determine how the community will take the attitude and action.

Keywords: policy implementation; RKL RPL detailed; industrial estate

\section{Pendahuluan}

Pasal 1 ayat (3) Undang-undang Dasar 1945 dinyatakan bahwa Negara Republik Indonesia adalah Negara Hukum, yang berarti bahwa hukum merupakan supremasi tertinggi, yang mengatur seluruh pelaksanaan kehidupan bermasyarakat, berbangsa dan bernegara. Hukum disini merupakan landasan atau dasar untuk pelaksanaan seluruh kegiatan, baik itu meliputi kegiatan tata negara, ekonomi, sosial, budaya bahkan bagaimana tata cara hidup bermasyarakat.

Hukum itu sendiri menurut Kamus Besar Bahasa Indonesia adalah peraturan atau adat yang secara resmi dianggap mengikat, yang dikukuhkan oleh penguasa atau pemerintah. Hukum memiliki produk berupa perundang-undangan atau kebijakan yang dibentuk oleh pemerintah atau lembaga Negara. Menurut Hamid A. S. Attamimi, pembentukan Peraturan perundang-undangan adalah pembentukan norma yang berlaku keluar dan mengikat secara umum, yang dituangkan dalam peraturan Perundangundangan sesuai hirarkinya (Attamimi et al., 1990).

Negara Indonesia adalah negara hukum yang dapat melakukan pemisahan dan pembagian kekuasaan didalam menjalankan sistem pemerintahannya, Janpatar Simamora menyatakan bahwa di Negara Indonesia Presiden menjalankan kekuasaan eksekutif, DPR dan DPD menjalankan kekuasaan legislatif, serta MA dan MK sebagai pelaksana kekuasaan Kehakiman atau kekuasaan Yudikatif (Simamora, 2015).

Kewajiban menyusun suatu Rancangan Undang-Undang, yang jika kemudian disetujui dan disahkan menjadi Undang-Undang merupakan tugas legislatif, dalam hal ini adalah DPR dan DPD. Suatu Perundang-undangan atau Kebijakan dibentuk dengan tujuan untuk mengatur tata cara berkehidupan masyarakat Indonesia menyangkut semua aktivitas yang dilakukannya. Suatu peraturan perundang-undangan atau kebijakan akan disusun secara ideal, tertata dan yang terutama adalah untuk melindungi hak-hak warga negaranya, yang sesuai dengan tujuan awal pembentukan Negara Republik Indonesia, yaitu adalah untuk mencapai kesejahteraan Rakyat (Suantra \& Nurmawati, 2019). 
Salah satu Undang-Undang terbaru yang banyak menarik perhatian masyarakat Indonesia, adalah Undang-Undang Nomor 11 Tahun 2020 Tentang Cipta Kerja. Undangundang ini banyak dianggap menjadi sebuah kontroversi, karena Undang-Undang Cipta kerja tersebut, banyak memuat dan menyentuh ranah undang-undang dan peraturan lainnya. Undang-undang Cipta kerja ini dibuat dan disusun dengan tujuan agar proses perizinan atau regulasi dapat dibuat dengan sederhana, sehingga dapat menarik investor dalam jumlah yang banyak (Siallagan, 2016).

Disahkannya Undang- Undang Cipta kerja pada tahun 2020, banyak membawa dampak bagi hampir seluruh peraturan perundang-undangan dan kebijakan yang ada, karena dengan ditetapkannya Undang-Undang Cipta Kerja tersebut, banyak Peraturan turunannya yang berubah, baik itu Peraturan Pemerintah, Peraturan Menteri, hingga Peraturan Daerah. Perubahan kebijakan yang hampir menyeluruh tentu saja menjadi tugas yang besar untuk pemerintah, baik pemerintah pusat ataupun pemerintah daerah, yang menjadi pelaksana sekaligus penanggung jawab penerapan perundang-undangan atau kebijakan yang ada.

Salah satu perubahan yang signifikan berkaitan dengan perizinan adalah adanya perubahan sistem pengurusan proses perizinan dari sistem Manual dan terpisah di masing-masing daerah, menjadi elektronik dan terpusat. Perubahan ini, diawali dengan diterapkannya Peraturan Pemerintah Nomor 24 Tahun 2018 tentang Pelayanan Perizinan Berusaha Terintegrasi secara Elektronik atau Online Single Submission (OSS), yang setelah terbitnya Undang-undang Cipta Kerja Tahun 2020, sebagai pelaksanaan ketentuan Pasal 12, diganti menjadi Peraturan Nomor 5 Tahun 2021, tentang Penyelengaraan Perizinan Berusaha Berbasis Risiko.

Sejak diberlakukannya Peraturan Pemerintah Nomor 24 Tahun 2018 yang kemudian diganti menjadi Peraturan Nomor 5 Tahun 2021 tersebut, hampir seluruh mekanisme proses perizinan usaha di Indonesia mengalami perubahan, salah satunya adalah berkaitan dengan proses perizinan bagi perusahaan atau pelaku usaha yang akan atau sudah melakukan kegiatan di dalam dalam kawasan ekonomi khusus, kawasan industri, atau kawasan perdagangan bebas dan pelabuhan bebas. Didalam Pasal 35 ayat (1) sampai dengan ayat (4), dinyatakan bahwa izin lingkungan tidak dipersyaratkan untuk penerbitan izin usaha bagi perusahaan atau pelaku usaha yang Lokasi usaha dan/atau kegiatannya berada dalam kawasan ekonomi khusus, kawasan industri, atau kawasan perdagangan bebas dan pelabuhan bebas, sehingga mereka tidak diwajibkan lagi untuk memiliki Dokumen Lingkungan Hidup berupa AMDAL (Analisis Mengenai Dampak Lingkungan) dan atau UKL UPL (Upaya Pengelolaan Lingkungan Hidup dan Upaya Pemantauan Lingkungan Hidup), namun hanya diwajibkan untuk menyusun Dokumen RKL RPL (Rencana Pengelolaan Lingkungan Hidup dan Rencana Pemantauan Lingkungan Hidup) Rinci, yang pelaksanaan dan pengawasannya diatur dengan peraturan menteri yang menyelenggarakan urusan pemerintahan di bidang perlindungan dan pengelolaan lingkungan Hidup.

Pada Tahun 2020, Pemerintah Indonesia kemudian menerbitkan Peraturan pendukung melalui Peraturan Menteri Perindustrian dan Perdagangan Nomor 1 Tahun 
2020, yang mengatur tentang penyusunan Rencana Pengelolaan lingkungan hidup dan rencana pemantauan lingkungan hidup bagi perusahaan yang berada atau akan berlokasi di Kawasan industri (Shoba, 2006).

Penerapan Peraturan Menteri Perindustrian dan Perdagangan Nomor 1 Tahun 2020 yang merupakan peraturan atau kebijakan baru ini, tentu saja akan menimbulkan dampak yang kendala tersendiri didalam pelaksanaannya, hal ini dikarenakan akan selalu ada perubahan tanggung jawab, peran serta aturan yang mengatur berbagai aspek serta pelaku yang ada didalamnya, yang dapat menghambat implementasi penerapan kebijakan tersebut, maka berdasarkan pemaparan tersebut diatas, penulis tertarik untuk mendeskripsikan dan menganalisis bagaimana implementasi kebijakan Peraturan Menteri Perindustrian dan Perdagangan Nomor 1 Tahun 2020 Tentang Penyusunan RKL RPL Rinci di Kawasan industri Blessindo Kabupaten Tangerang. Melalui Penelitian ini penulis akan mencoba menganalisis bagaimana proses suatu kebijakan baru diimplementasikan di lapangan, serta apa saja hambatan dan Upaya yang ada pada suatu proses implementasi kebijakan baru.

Tujuan dari penelitian ini adalah untuk mengetahui bagaimana Implementasi Kebijakan Peraturan Menteri Perindustrian dan Perdagangan Nomor 1 Tahun 2020 Tentang Penyusunan RKL RPL Rinci di Kawasan industri Blessindo Kabupaten Tangerang, sebagai salah satu kebijakan yang baru diterapkan oleh Pemerintah Indonesia. Mengetahui kendala-kendala apakah yang timbul dalam implementasi kebijakan Menteri Perindustrian dan Perdagangan Nomor 1 Tahun 2020 di Kawasan industri Blessindo Kabupaten Tangerang. Mengetahui upaya-upaya apakah yang perlu dilakukan oleh Pihak Pengelola Kawasan industri Blessindo serta Dinas Lingkungan Hidup dan Kebersihan Kabupaten Tangerang untuk mengurangi kendala-kendala yang timbul dalam penerapan Peraturan Menteri Perindustrian dan Perdagangan Nomor 1 Tahun 2020 di Kawasan industri Blessindo Kabupaten Tangerang.

\section{Metode Penelitian}

Metode penelitian yang gunakan adalah metode pendekatan yuridis empiris, pendekatan ini merupakan pendekatan yang menggabungkan data-data primer dan sekunder didalam penelitian yang dilakukan. Pada penelitian yuridis empiris, tahap awal yang dilakukan adalah mengkaji permasalahan dengan menggunakan peraturan yang ada, baik peraturan tertulis ataupun tidak tertulis, yang menjadi data sekunder dalam penelitian ini, untuk kemudian dianalisis dengan hasil yang didapatkan dari data primer yaitu melalui wawancara terstruktur yang dilaksanakan dilapangan untuk mengetahui bagaimana implementasi Peraturan Menteri Perindustrian dan Perdagangan Nomor 1 Tahun 2020 Tentang Penerapan RKL RPL Rinci di Kawasan industri Blessindo Kabupaten Tangerang.

Ruang lingkup atau fenomena yang diamati tentang pembatasan keluasan dan kedalaman cakupan penelitian. Fenomena penelitian adalah suatu gejala yang mendasar atau suatu kejadian, peristiwa tentang perilaku-perilaku yang diamati, atau proses aksi interaksi yang saling berkaitan. Penelitian ini dilakukan guna untuk mendapatkan bahan- 
bahan berupa teori-teori, konsep-konsep, asas-asas hukum serta peraturan hukum yang berhubungan dengan pokok bahasan. Ruang lingkup penelitian hukum normatif menurut (Soekanto, 2005) meliputi:

1. Penelitian terhadap asas-asas hukum.

2. Penelitian terhadap sistematika hukum.

3. Penelitian terhadap taraf sinkronisasi hukum secara vertikal dan horizontal.

4. Perbandingan hukum.

5. Sejarah hukum.

Lokasi penelitian ini yaitu di Kawasan industri Blessindo, Cirarab, Kec. Legok, Tangerang, Banten 15820. Sampel dalam penelitian ini diambil dengan menggunakan teknik nonrandom secara purposive sampling dimana penarikan sampel dilakukan dengan cara mengambil subjek berdasarkan pada tujuan tertentu. Dalam penelitian ini sampel yang diambil dari populasi adalah perusahan yang ada di kawasan industri Blessindo Kabupaten Tangerang. Sedangkan responden dalam penelitian ini adalah:

1. Tenant atau Perusahaan Yang ada di dalam Kawasan industri Blessindo Kabupaten Tangerang

2. Pengelola Kawasan industri Blessindo Tangerang

3. Pejabat Dinas Lingkungan Hidup dan Kebersihan Kabupaten Tangerang.

Data yang digunakan dalam penelitian ini adalah data primer dan data sekunder. Data primer adalah data yang diperoleh langsung dari instansi terkait melalui penelitian lapangan. Sedangkan data sekunder dalam penelitian ini mencakup:

1. Bahan-bahan hukum primer, meliputi: Pancasila, UUD 1945, Peraturan Perundangundangan dan yurisprudensi.

2. Bahan-bahan hukum sekunder, meliputi: buku teks, laporan penelitian, artikel ilmiah.

3. Bahan hukum tersier, bahan ini sebagai pedoman untuk mengkaji bahan hukum primer dan bahan sekunder, yang diperoleh dari kamus hukum, kamus bahasa

Indonesia maupun bahasa Inggris, ensiklopedi, surat kabar maupun majalah.

Studi ini dilakukan terhadap dokumen-dokumen dan bahan-bahan pustaka yang berkaitan dengan permasalahan yang akan diteliti. Selain studi kepustakaan, alat pengumpul data yang dipergunakan dalam penelitian lapangan adalah wawancara dengan menggunakan pedoman wawancara. Mula-mula kepada responden diajukan pertanyaan yang sudah terstruktur, kemudian beberapa butir pertanyaan tersebut diperdalam. Hasil dari wawancara ini diharapkan dapat memberikan gambaran secara komprehensif tentang pembangunan Kawasan Industri dalam menunjang minat investasi di Kabupaten Tangerang.

Setelah keseluruhan data primer dan data sekunder terkumpul, langkah yang diambil peneliti selanjutnya adalah mengolah dan melakukan analisis data. Pengolahan data dilakukan dengan tujuan untuk merapikan data hasil pengumpulan data dilapangan sehingga siap pakai untuk dianalisis. Selanjutnya data yang ada akan dianalisis secara kualitatif. Analisis ini dapat diperoleh gambaran secara utuh atas masalah yang menjadi pembahasan. 


\section{Hasil dan Pembahasan}

\section{A. Implementasi Kebijakan Peraturan Menteri Perindustrian dan Perdagangan} Nomor 1 Tahun 2020 Tentang Penyusunan RKL RPL Rinci di Kawasan industri Blessindo Kabupaten Tangerang.

Pemerintah bertekad menciptakan iklim bisnis yang kondusif di Tanah Air. Salah satunya adalah dengan memberikan kemudahan bagi para pelaku usaha dalam mengurus mekanisme perizinan. Langkah strategis ini tertuang pada Peraturan Pemerintah Nomor 24 Tahun 2018 tentang Pelayanan Perizinan Berusaha Terintegrasi Secara Elektronik, yang telah diganti oleh Peraturan Pemerintah Nomor 5 Tahun 2020 Tentang Penyelenggaraan Perizinan Berusaha Berbasis Risiko.

Salah satu implikasi yang paling berdampak untuk para pelaku usaha dan kegiatan adalah dihilangkannya kewajiban dari para pelaku usaha yang ada atau berencana untuk melakukan kegiatan di dalam kawasan industri, untuk menyusun dokumen lingkungan hidup baik berupa Amdal ataupun UKL UPL yang semula harus dinilai dan diserahkan kepada Pemerintah Daerah atau Pusat sesuai dengan jenis kegiatan dan kewenangan penilaiannya, sekarang hanya diwajibkan untuk melakukan penyusunan Dokumen RKL RPL Rinci, yang penilaiannya dilaksanakan oleh pemilik atau pengelola kawasan.

Mengatur teknis pelaksanaan kebijakan tersebut diatas, pemerintah melalui Kementerian Perdagangan dan Perindustrian mengeluarkan suatu kebijakan dalam bentuk Peraturan Menteri Perindustrian dan Perdagangan Nomor 1 Tahun 2020 tentang Penyusunan Rencana Pengelolaan Lingkungan Hidup dan Rencana Pemantauan Lingkungan Hidup (RKL RPL) Rinci bagi perusahaan industri yang berada atau berlokasi di Kawasan industri. Lawrence Meir Friedman menyatakan bahwa untuk menilai berhasil atau tidaknya suatu hukum atau kebijakan tergantung dari tiga elemen utama, yaitu:

1. Substansi Hukum

Substansi hukum merupakan sistem yang menentukan apakah suatu hukum atau kebijakan dapat dilaksanakan atau tidak. Substansi hukum disini adalah isi atau muatan dari Peraturan Menteri Perdagangan dan Perindustrian Nomor 1 Tahun 2020 ini sendiri.

Kita jabarkan substansi atau muatan dari peraturan Peraturan Menteri Perdagangan dan Perindustrian Nomor 1 Tahun 2020 tersebut memuat enam bab, yang terdiri dari:

-Bab I : Ketentuan Umum

-Bab II : Penyusunan dan Permohonan Persetujuan RKL RPL Rinci

-Bab III: Pemeriksaan dan Persetujuan RKL RPL Rinci

-Bab IV: Pembiayaan

-Bab V : Pembinaan Pemantauan dan Pengawasan Pelaksanaan RKL RPL Rinci

-Bab IV: Ketentuan Peralihan

-Bab VII: Penutup 
-Lampiran 1: Tambahan penjelasan atau lampiran mengenai Format surat dan formulir dalam rangka penyusunan rencana pengelolaan lingkungan hidup dan rencana pemantauan lingkungan hidup rinci bagi perusahaan industri yang berada atau akan berlokasi di kawasan industri.

Garis besar substansi peraturan menteri tersebut, kita dapat melihat bahwa secara substansi proses pelaksanaan penyusunan dokumen rkl rpl rinci mulai dari pihak-pihak yang diwajibkan untuk menyusun dokumen rkl rpl rinci, pihak yang dapat melaksanakan penyusunan dokumen rkl rpl rinci, pihak yang menilai dan mengawasi penyusunan dokumen rkl rpl rinci, serta pihak yang mengawasi berjalannya implementasi kebijakan tersebut sudah termuat didalam Peraturan Menteri tersebut dengan jelas. Selain itu, didalam Peraturan Menteri tersebut telah dijelaskan tentang tata cara penyusunan dokumen $\mathrm{rkl} \mathrm{rpl}$ rinci, tata cara penilaian dokumen rkl rpl rinci, serta hak dan kewajiban dari masing-masing pihak.

Sehingga secara sistematis Peraturan Menteri Perdagangan dan Perindustrian Nomor 1 Tahun 2020 ini sudah dapat dilaksanakan oleh pihak-pihak yang tercantum dalam peraturan menteri tersebut, yaitu:

a. Pelaku usaha yang sudah dan atau akan melaksanakan kegiatan usaha di kawasan industri, selaku penyusun dokumen rkl rpl rinci.

b. Pemilik atau pengelola kawasan industri, selaku penilai dan pengawas penyusunan dokumen rkl rpl rinci.

c. Pemerintah pusat dan pemerintah daerah selaku pengawas terhadap implementasi kebijakan Peraturan Menteri Perdagangan dan Perindustrian Nomor 1 Tahun 2020 tersebut.

Berkaitan dengan Substansi hukum ini, Lawrence Meir Friedman pun menyatakan bahwa, dalam penilaian mengenai aspek substansi hukum, kita harus memperhatikan hukum yang hidup, baik itu berupa peraturan tertulis ataupun peraturan yang tidak tertulis, menyangkut dari hukum atau kebijakan yang sedang kita teliti. Maka disini kita harus mengetahui hukum atau kebijakan yang terkait dengan Peraturan Menteri Perdagangan dan Perindustrian Nomor 1 Tahun 2020 ini, adapun beberapa hukum dan kebijakan yang terkait adalah:

Undang-undang nomor 32 Tahun 2009 tentang Perlindungan dan Pengelolaan Lingkungan Hidup, yang telah diganti oleh Undang-undang nomor 11 tahun 2020 tentang Cipta Kerja.

a. Peraturan Pemerintah Tahun 24 Tahun 2018 Tentang Pelayanan Perizinan Berusaha Terintegrasi Secara Elektronik, yang telah diganti oleh Peraturan Pemerintah nomor 5 tahun 2021 tentang Penyelenggaraan Perizinan Berusaha Berbasis Risiko.

b. Peraturan Pemerintah Nomor 27 Tahun 2012 Tentang Izin Lingkungan, yang telah diganti oleh Peraturan Pemerintah nomor 22 Tahun 2021 tentang penyelenggaraan Perlindungan dan Pengelolaan Lingkungan Hidup.

c. Peraturan Menteri Lingkungan Hidup dan Kehutanan nomor 26 tahun 2018 tentang Pedoman Penyusunan dan Pemeriksaan Dokumen Lingkungan Hidup 
Dalam Pelaksanaan Pelayanan Perizinan Berusaha Secara Elektronik (OSS), yang diganti oleh Peraturan Menteri Perindustrian dan Perdagangan Nomor 1 Tahun 2020 tentang Penyusunan Rencana Pengelolaan Lingkungan Hidup dan Rencana Pemantauan Lingkungan Hidup Rinci Bagi Perusahaan Industri Yang Berada atau akan Berlokasi di Kawasan industri.

d. Peraturan Menteri Perindustrian dan Perdagangan No. 15 Tahun 2019 tentang Penerbitan Izin Usaha Industri dan Izin Perluasan Dalam Kerangka Pelayanan Perizinan Berusaha Terintegrasi Secara Elektronik, yang telah diganti oleh Peraturan Menteri Perindustrian dan Perdagangan No. 30 Tahun 2019, tentang perubahan atas Peraturan Menteri Perindustrian dan Perdagangan No. 15 Tahun 2019 tentang Penerbitan Izin Usaha Industri dan Izin Perluasan Dalam Kerangka Pelayanan Perizinan Berusaha Terintegrasi Secara Elektronik.

Berdasarkanberbagai peraturan tersebut diatas, kita dapat menyimpulkan bahwa, aspek substansi hukum dalam implementasi kebijakan Menteri Perindustrian dan Perdagangan Nomor 1 Tahun 2020 tentang Penyusunan Rencana Pengelolaan Lingkungan Hidup dan Rencana Pemantauan Lingkungan Hidup Rinci Bagi Perusahaan Industri Yang Berada atau akan Berlokasi di Kawasan industri sudah terpenuhi, sehingga kebijakan ini seharusnya sudah dapat diimplementasikan, karena substansi dalam kebijakan tersebut telah memuat berbagai pengaturan terhadap permasalahan yang berhubungan dengan perubahan kebijakan yang ada.

2. Struktur Hukum

Struktur hukum adalah perangkat yang menentukan apakah suatu hukum atau kebijakan dapat ditegakan atau tidak. Berdasarkan Undang-undang Nomor 8 Tahun 1981, struktur hukum adalah meliputi Kepolisian, kejaksaan, pengadilan, Badan Pelaksana Pidana (LAPAS), kewenangan lembaga penegak hukum tersebut dijamin oleh Undang-Undang, sehingga dalam pelaksanaan tugas dan tanggung jawab terlepas dari pergantian kekuasaan pemerintah atau pengaruh-pengaruh yang lainnya.

Penegakan hukum yang berkaitan dengan lingkungan sudah dimulai sejak diterapkannya Undang-Undang No 32 Tahun 2009 tentang perlindungan dan pengelolaan lingkungan yang sekarang telah menjadi telah menjadi UndangUndang No 11 Tahun 2020 tentang Cipta Kerja (Ansori, 2018). Sarana penegakan hukum tersebut dilakukan melalui tiga tahap yaitu:

a. Sanksi Administrasi

Sanksi administrasi merupakan tahap pertama yang akan dikenakan kepada pelaku usaha atau perusahaan yang terbukti melakukan pencemaran atau pengrusakan terhadap lingkungan. Sanksi administrasi ini tercantum dalam Pasal 76 ayat (2) Undang-Undang No 32 tahun 2009, yang menjelaskan bahwa sanksi administrasi terdiri dari:

1) teguran tertulis

2) paksaan pemerintah 
3) pembekuan izin lingkungan

4) pencabutan izin lingkungan

Sanksi administrasi ini merupakan fungsi instrumental yang berfungsi untuk mencegah dan menanggulangi pelanggaran terhadap lingkungan hidup. Pemberian sanksi ini dilaksanakan dengan tujuan agar pelanggaran terhadap aturan dapat dihentikan secara langsung. Dalam hal ini, kepala daerah berhak dan memiliki wewenang untuk mengajukan usul pencabutan usaha kepada pejabat yang berwenang, terutama jika ada aduan dari masyarakat yang terganggu kesehatannya akibat pencemaran yang terjadi.

Sanksi administrasi ini biasanya diberikan oleh Pemerintah dalam hal ini Kementerian Lingkungan Hidup dan Kehutanan Republik Indonesia untuk penyelenggara kegiatan yang berada di kewenangan Pusat, atau dari Dinas Lingkungan Hidup dan Kehutanan atau Dinas Lingkungan Hidup dan Kebersihan untuk yang kegiatannya berada di kewenangan Pemerintah Daerah Provinsi atau Kota atau Kabupaten.

b. Sanksi Perdata

Sanksi perdata merupakan tindakan hukum yang kedua yang diberikan terhadap perusahaan yang melakukan pencemaran dan perusakan lingkungan. Terhadap penyelesaian sengketa lingkungan hidup untuk menggugat ganti kerugian dan atau biaya pemulihan lingkungan hidup, terdapat dua jalur ( Pasal 84 UU No. 32 Tahun 2009 tentang Perlindungan dan Pengelolaan Lingkungan Hidup ) yaitu:

1) Penyelesaian sengketa lingkungan hidup di luar pengadilan.

2) Penyelesaian sengketa lingkungan hidup melalui pengadilan.

Penyelesaian sengketa lingkungan hidup diluar pengadilan menurut Pasal 85 dan Pasal 86 UU No. 32 Tahun 2009 tentang Perlindungan dan Pengelolaan Lingkungan Hidup menyatakan bahwa penyelesaian sengketa lingkungan hidup diluar pengadilan diselenggarakan untuk mencapai kesepakatan mengenai bentuk dan besarnya ganti kerugian dan atau mengenai tindakan tertentu guna menjamin tidak terjadinya atau terulangnya dampak negatif terhadap lingkungan hidup (Yuliana, Purnaweni, \& Rengga, 2015). Hal ini dilakukan secara sukarela oleh pihak yang berkepentingan, yaitu pihak yang dirugikan dan yang mengakibatkan kerugian, instansi pemerintah yang terkait serta dapat pula melibatkan pihak yang mempunyai kepedulian terhadap pengelolaan lingkungan hidup. Penyelesaian melalui cara ini dilakukan dengan cara mediasi lingkungan, akibat hukum mediasi lingkungan yang oleh para pihak biasanya dituangkan dalam bentuk persetujuan mediasi tertulis yang dianggap berkekuatan hukum sebagai kontrak yang tunduk pada ketentuan BW.

c. Sanksi Pidana

Sanksi pidana merupakan aspek tindakan hukum yang terakhir. Sanksi pidana diberikan terhadap perusahaan yang melakukan pencemaran dan perusakan lingkungan, mempunyai fungsi untuk mendidik perusahaan 
sehubungan dengan perbuatan yang dilakukan, terutama ditujukan terhadap perlindungan kepentingan umum yang dijaga oleh ketentuan hukum yang dilanggar tersebut. Selain itu fungsinya juga untuk mencegah atau menghalangi pelaku potensial agar tidak melakukan perilaku yang tidak bertanggung jawab terhadap lingkungan hidup.

Menjatuhkan pidana untuk kasus lingkungan pada perusahaan maka juga berlaku peraturan-peraturan seperti kasus pidana lainnya yaitu asas legalitas maksudnya harus berdasarkan hukum yang ada pada saat perbuatan itu dilakukan dan harus terbukti kesalahannya.

Ancaman pidana sebagaimana tercantum dalam pasal-pasal UU No. 32 Tahun 2009 tentang Perlindungan dan Pengelolan Lingkungan Hidup adalah pidana penjara dan denda. Selain itu ada pidana tambahan atau tindakan tata tertib terhadap badan usaha Pasal 119 UU No.32 Tahun 2009 berupa:

1) Perampasan keuntungan yang diperoleh dari tindak pidana.

2) Penutupan seluruh atau sebagian tempat usaha dan / atau kegiatan.

3) Perbaikan akibat tindak pidana.

4) Kewajiban mengerjakan apa yang dilalaikan tanpa hak.

5) Penempatan Perusahaan dibawah pengampuan paling lama 3 (tiga) tahun

3. Budaya Hukum

Budaya Hukum menurut (Friedman \& Hayden, 2017) adalah sikap manusia terhadap hukum dan sistem hukum, kepercayaan, nilai pemikiran serta harapannya. Budaya hukum disini merupakan keadaan atau kekuatan sosial, yang menentukan bagaimana hukum tersebut digunakan, dihindari atau disalahgunakan, sehingga budaya hukum ini erat kaitannya dengan kesadaran hukum di dalam suatu masyarakat. Suatu masyarakat yang taat kepada hukum, akan dianggap memiliki budaya hukum yang baik, dan sebaliknya suatu masyarakat yang ketaatan terhadap hukumnya rendah, maka dapat dikatakan bahwa budaya hukum yang mereka miliki adalah kurang baik (Pertiwi, 2018).

Maka implementasi kebijakan peraturan disini lebih berkenaan kepada bagaimana masyarakat mempercayai dan meyakini bahwa suatu kebijakan atau peraturan yang ada, dapat membawa manfaat bagi masyarakat disekitar lingkungannya, ketika mereka mengetahui bahwa peraturan yang ada akan melindungi mereka dan lingkungan yang ada disekitarnya, maka kecenderungan untuk mentaati peraturan itu akan tinggi, namun jika masyarakat merasa bahwa kebijakan tersebut tidak mengakomodir kebutuhan mereka, maka masyarakat akan cenderung untuk menolak atau membiarkan segala bentuk kebijakan yang ada (Purba, 2017).

Proses implementasi sebuah peraturan baru, memang dibutuhkan komunikasi yang baik dan terarah dari pemerintah ataupun pemilik kawasan terhadap masyarakat yang ada disekitar lokasi kegiatan. Jika pemerintah mampu berkoordinasi dengan aparatur setempat seperti di tingkat Desa dan Kecamatan, maka biasanya sebuah peraturan akan lebih mudah diterima oleh masyarakat, 
sedangkan untuk kebijakan yang melibatkan pelaku usaha, jika mereka mampu mengelola kegiatan usahanya agar tidak mencemari lingkungan, dan melakukan menjalin hubungan baik dengan masyarakat yang ada disekitar lokasi kegiatan, misalnya melalui kegiatan CSR, maka kecenderungan masyarakat untuk menerima kebijakan tersebut akan cenderung tinggi.

\section{B. Kendala-Kendala Dalam Implementasi Kebijakan Peraturan Menteri Perindustrian dan Perdagangan Nomor 1 Tahun 2020.}

1. Substansi Hukum

Penerapan kebijakan teknis, dalam hal ini substansi yang ada didalam Peraturan Menteri Perindustrian dan Perdagangan Nomor 1 Tahun 2020 seringkali tidak konsisten dengan substansi yang ada didalam Peraturan yang ada diatasnya, yaitu Peraturan Pemerintah No. 24 Tahun 2018, yang telah diganti oleh Peraturan Pemerintah nomor 5 Tahun 2021, misalnya pada Pasal 53 ayat (4) yang menyatakan bahwa pelaksanaan dan pengawasannya diatur dengan peraturan menteri yang menyelenggarakan urusan pemerintahan di bidang perlindungan dan pengelolaan lingkungan Hidup. Sedangkan seperti yang kita ketahui bahwa Peraturan ini dikeluarkan oleh Kementrian Perindustrian dan Perdagangan, sehingga dalam pelaksanaan kewenangan, terutama didaerah dalam hal ini di Kabupaten sendiri ada kerancuan wewenang, apakah pelaksanaan penyelenggaraan peraturan ini ada di bawah pengawasan Dinas Lingkungan Hidup dan Kebersihan Kabupaten Tangerang atau ada di Dinas Perindustrian dan Perdagangan Kabupaten Tangerang. Yang Jelas dari hasil wawancara yang peneliti lakukan dengan pejabat dari Dinas Lingkungan Hidup Tangerang, belum ada sama sekali kawasan industri di Kabupaten Tangerang yang telah menerapkan kebijakan ini, sehingga perusahaan atau pelaku usaha yang ada dikawasan industri masih menyusun dokumen lingkungan berupa dokumen UKL UPL yang masih dinilai oleh Dinas Lingkungan Hidup dan Kebersihan Kabupaten Tangerang (Ulih, 2016).

Permasalahan lainnya yang cukup menjadi hambatan untuk penerapan implementasi kebijakan ini adalah, adanya peralihan tanggung jawab penilaian penyusunan dokumen lingkungan dari pemerintah daerah, dalam hal ini Dinas Lingkungan Hidup Kabupaten Tangerang kepada pengelola kawasan. Padahal dalam wawancara yang dilakukan dengan pengelola kawasan, mereka sendiri belum mendapatkan informasi tentang kebijakan tersebut, serta mereka tidak memiliki sumber daya manusia dan sarana seperti yang dipersyaratkan dalam peraturan tersebut.

2. Struktur Hukum

Kendala yang seringkali dihadapi dalam implementasi kebijakan sebuah Peraturan adalah berkaitan dengan Sarana hukum dan aparat hukum itu sendiri. Dalam kaitannya dengan sarana hukum, fasilitas serta sarana penunjang dalam pelaksanaan penegakan dan pengawasan berjalannya suatu peraturan seringkali tidak memadai misalnya sumber daya manusia serta biaya operasional yang tidak memadai untuk melakukan pengawasan. Sedangkan berkaitan dengan aparatur 
hukum itu sendiri, banyak kasus-kasus lingkungan terkendala dikarenakan jumlah aparat penegak hukum profesional yang mampu menangani kasus-kasus lingkungan masih sangat terbatas. Disamping itu adalah mustahil kiranya kita mengharapkan para penegak hukum itu dapat menguasai berbagai aspek lingkungan. Karena lingkungan hidup mencakup aspek yang sangat luas dan kompleks yang berkenaan dengan berbagai disiplin ilmu. Keterbatasan pengetahuan dan pemahaman aspek-aspek lingkungan oleh penegak hukum menjadi faktor kendala yang sangat dominan dalam upaya untuk menciptakan kesamaan persepsi penanganan perkara lingkungan

3. Budaya Hukum

Berdasarkan hasil penelitian yang didapatkan dari hasil wawancara dengan masyarakat setempat, didapatkan gambaran bahwa masyarakat belum mengetahui mengenai adanya peraturan Peraturan Menteri Perindustrian dan Perdagangan Nomor 1 Tahun 2020 tentang Penyusunan Rencana Pengelolaan Lingkungan Hidup dan Rencana Pemantauan Lingkungan Hidup Rinci Bagi Perusahaan Industri Yang Berada atau akan Berlokasi di Kawasan industri. Kurangnya informasi dan pengetahuan masyarakat mengenai peraturan pemerintah ini akan sangat mempengaruhi persepsi masyarakat terhadap keberadaan suatu kegiatan dan akan menentukan bagaimana masyarakat akan mengambil sikap dan tindakan. Menurut (Chasanah, 2017), pengetahuan adalah suatu daya didalam hidup manusia. Dengan pengetahuan manusia mengenali peristiwa dan permasalahan, menganalisa, mengurai, mengadakan interpretasi dan menentukan pilihan-pilihan. Dengan daya pengetahuan ini manusia mempertahankan dan mengembangkan hidup dan kehidupan. Bermodal kepada daya itu manusia membentuk sikap dan nilai hidup, menentukan pilihan-pilihan dan tindakan-tindakan.

Berkaitan dengan implementasi peraturan menteri nomor 1 tahun 2020 ini, masyarakat seharusnya harus dibekali dengan pengetahuan yang benar mengenai lingkungan dan bagaimana kewajiban dari para pelaku usaha dalam melakukan pengelolaan terhadap lingkungan, sehingga persepsi adanya kegiatan usaha industri yang ada dilingkungan sekitar mereka, dapat terbentuk secara baik. Disini masyarakat sebenarnya dapat berfungsi sebagai mitra perusahaan untuk sama-sama menanggulangi pencemaran yang ada. Namun pada kenyataannya di lapangan kita sering menemukan adanya kesenjangan pengetahuan masyarakat terhadap pengelolaan lingkungan itu sendiri, sehingga masyarakat tidak terlibat dalam menentukan sikap dan tindakan dalam suatu kebijakan (Jainah, 2011).

Sebenarnya gap pengetahuan ini dapat dikurangi dengan adanya edukasi dari pemerintah setempat mengenai pengelolaan lingkungan, terutama bagi masyarakat yang termasuk dalam wilayah peruntukan bagi industri. Kualitas lingkungan yang baik sangat tergantung pada persepsi masyarakat terhadap kualitas lingkungan. kualitas lingkungan yang baik dapat tercapai secara optimal sesuai dengan harapan dan keinginan masyarakat mengenai kualitas suatu lingkungan. Bila persepsi masyarakat mengenai lingkungan didukung oleh pengetahuan masyarakat tentang 
kualitas lingkungan yang baik dan cara mencapainya, tentunya akan sangat mempengaruhi setiap tindakan atau perlakuan yang diambil terhadap lingkungan sekitarnya. Masyarakat akan mengetahui setiap perubahan yang mungkin akan terjadi bila ada suatu kegiatan disekitarnya (Prameswari, Resen, \& Dahana, 2014).

\section{Upaya-Upaya yang dilakukan dalam Mengatasi Kendala-Kendala yang Ada}

1. Substansi Hukum

a. Peraturan Menteri Perindustrian dan Perdagangan Nomor 1 Tahun 2020 tentang Penyusunan Rencana Pengelolaan Lingkungan Hidup dan Rencana Pemantauan Lingkungan Hidup Rinci Bagi Perusahaan Industri, Pemerintah Pusat perlu secara jelas memberikan batasan waktu maksimal pemberlakukan Peraturan ini kepada Pemerintah Daerah.

b. Perlu ada pendelegarian atau garis tugas yang jelas tentang kewenangan pelaksanaan pengawasan implementasi kebijakan Peraturan Menteri Perindustrian dan Perdagangan Nomor 1 Tahun 2020 tentang Penyusunan Rencana Pengelolaan Lingkungan Hidup dan Rencana Pemantauan Lingkungan Hidup Rinci Bagi Perusahaan Industri Yang Berada atau akan Berlokasi di Kawasan industri ini.

c. Pemerintah Daerah Kabupaten Tangerang perlu memberikan pengarahan dan informasi yang jelas kepada Pemilik atau Pengelola Kawasan tentang Tata cara pelaksanaan peraturan menteri ini, terutama tentang sistem penilaian dokumen lingkungan hidup, yang harus dilakukan.

2. Struktur Hukum

a. Perlu adanya pembiayaan dan penyediaan sarana yang jelas untuk para penegak hukum, sehubungan dengan pengawasan penerapan kebijakan baik untuk Peraturan Menteri Perindustrian dan Perdagangan Nomor 1 Tahun 2020 tentang Penyusunan Rencana Pengelolaan Lingkungan Hidup dan Rencana Pemantauan Lingkungan Hidup Rinci Bagi Perusahaan Industri Yang Berada atau akan Berlokasi di Kawasan industri ini sendiri, ataupun implementasi peraturan yang lainnya.

b. Perlu dibentuknya badan atau aparatur hukum yang secara khusus mengawasi berjalannya pengelolaan dan pemantauan lingkungan hidup

c. Perlu adanya pembekalan atau pelatihan berkaitan dengan pengelolaan dan pemantauan lingkungan bagi para aparatur hukum, sehingga mereka mengetahui kewajiban dan hak dari pada pelaku usaha, pemerintah serta masyarakat yang terlibat dalam suatu kegiatan yang berhubungan dengan kegiatan usaha, dampak yang ditimbulkan serta pengelolaan lingkungan hidup dan pemantauan lingkungan hidup.

3. Budaya Hukum

a. Perlu adanya sosialisasi dan koordinasi yang baik antara pemerintah dengan aparat desa atau kecamatan sehubungan dengan implementasi Peraturan Menteri Perindustrian dan Perdagangan Nomor 1 Tahun 2020 tentang Penyusunan Rencana Pengelolaan Lingkungan Hidup dan Rencana Pemantauan Lingkungan 
Hidup Rinci Bagi Perusahaan Industri Yang Berada atau akan Berlokasi di Kawasan industri.

b. Perlu adanya komunikasi yang baik antara pihak pelaku usaha baik dalam hal ini sebagai pengelola kawasan, ataupun pelaku usaha yang ada dialam kawasan industri dengan pihak aparat pemerintah setempat, dalam hal ini ditingkat Desa dan Kecamatan, sehingga dapat meminimalisir konflik yang akan timbul.

c. Perusahaan harus melakukan kegiatan CSR kepada masyarakat, sesuai dengan kebijakan yang telah ditetapkan oleh Pemerintah Kabupaten Tangerang.

\section{Kesimpulan}

Implementasi Kebijakan Peraturan Menteri Perindustrian dan Perdagangan Nomor 1 Tahun 2020 tentang Penyusunan Rencana Pengelolaan Lingkungan Hidup dan Rencana Pemantauan Lingkungan Hidup Rinci Bagi Perusahaan Industri Yang Berada atau akan Berlokasi di Kawasan industri, pada Kawasan industri Blessindo Kabupaten Tangerang belum dilaksanakan di Kawasan industri Blessindo Kabupaten Tangerang. Tiga sistem unsur dalam penegakan suatu kebijakan atau peraturan dapat dilihat dari tiga unsur, yaitu adalah Substansi Hukum, Struktur Hukum dan Budaya Hukum. Substansi hukum yang termuat dalam Peraturan Menteri Perindustrian dan Perdagangan Nomor 1 Tahun 2020 secara substansial, semua pengaturan pelaksanaan telah terakomodir dengan jelas didalam peraturan tersebut, namun sosialisasi implementasi kebijakan ini masih sangat kurang memadai, sehingga banyak pengelola kawasan yang tidak siap menerapkan peraturan ini dalam waktu yang dekat, dikarenakan terbatasnya sumber daya manusia dan sarana yang mereka miliki. Struktur Hukum atau pranata hukum, yang berfungsi sebagai penegak hukum belum berjalan secara maksimal, hal ini karena belum adanya garis koordinasi yang jelas antara pemerintah dan aparat hukum dalam pelaksanaan dan pengawasan penerapan sebuah kebijakan. Budaya Hukum merupakan hal yang harus sangat diperhatikan oleh pemerintah baik pusat ataupun pemerintah daerah dalam implementasi sebuah kebijakan, karena tanpa adanya dukungan yang positif dari masyarakat, implementasi sebuah kebijakan tidak akan berjalan dengan maksimal, namun seringkali, masyarakat itu sendiri, tidak mengetahui tentang berbagai kebijakan yang ada, padahal banyak kebijakan itu yang berdampak terhadap kehidupan masyarakat, terutama yang berkaitan langsung dengan kegiatan industri. 


\section{BIBLIOGRAFI}

Ansori, Lutfil. (2018). Reformasi Penegakan Hukum Perspektif Hukum Progresif. Jurnal Yuridis, 4(2), 148-163. Google Scholar

Attamimi, A. Hamid S., Wahyono, Padmo, Suny, Ismail, Martosoewignjo, Sri Soemantri, Soekanto, Soerjono, Budiardjo, Miriam, Rahardjo, Sutjipto, Hardjasoemantri, Koesnadi, \& Basah, Sjachran. (1990). Peranan Keputusan Presiden Republik Indonesia Dalam Penyelenggaraan Pemerintahan Negara: Suatu Studi Analisis Mengenai Keputusan Presiden Yang Berfungsi Pengaturan Dalam Kurun Waktu Pelita I-Pelita Iv. Google Scholar

Chasanah, Uswatun. (2017). Ontologi, Epistemologi Dan Aksiologi Pendidikan. Tasyri': Jurnal Tarbiyah-Syari'ah Islamiyah, 24(01), 77-92. Google Scholar

Friedman, Lawrence Meir, \& Hayden, Grant M. (2017). American Law: An Introduction. Oxford University Press. Google Scholar

Jainah, Zainab Ompu. (2011). Membangun Budaya Hukum Masyarakat Penegak Hukum Dalam Pemberantasan Tindak Pidana Narkotika. Keadilan Progresif, 2(2). Google Scholar

Pertiwi, Endah. (2018). Tanggung Jawab Notaris Akibat Pembuatan Akta Nominee Yang Mengandung Perbuatan Melawan Hukum Oleh Para Pihak. Jurnal Ius Kajian Hukum Dan Keadilan, 6(2), 245-258. Google Scholar

Prameswari, K., Resen, M., \& Dahana, C. (2014). Efektivitas Peraturan Daerah Kabupaten Klungkung Nomor 2 Tahun 2014 Tentang Ketertiban Umum Terkait Penyalahgunaan Fungsi Trotoar Sebagai Tempat Parkir. Google Scholar

Purba, Iman Pasu. (2017). Penguatan Budaya Hukum Masyarakat Untuk Menghasilkan Kewarganegaraan Transformatif. Jurnal Civics: Media Kajian Kewarganegaraan, 14(2), 146-153. Google Scholar

Shoba, Ana. (2006). Evaluasi Pelaksanaan Pengelolaan Dan Pemantauan Lingkungan Pada Beberapa Industri Di Kabupaten Tangerang. Program Pascasarjana Universitas Diponegoro. Google Scholar

Siallagan, Haposan. (2016). Penerapan Prinsip Negara Hukum Di Indonesia. Sosiohumaniora, 18(2), 122-128. Google Scholar

Simamora, Janpatar. (2015). Comparison Of Constitutional Court Authority Between Indonesia And South Korea. Jurnal Dinamika Hukum, 15(3), 331-338. Google Scholar

Soekanto, Soerjono. (2005). Hukum Adat Indonesia. Google Scholar

Suantra, I. Nengah, \& Nurmawati, Made. (2019). Penegakan Hukum Terhadap 
Implementasi Permenperin No. 1 Tahun 2020 tentang RKL RPL Rinci di Kawasan Industri

Pelanggaran Atas Ketentuan Perizinan Toko Swalayan Di Wilayah Provinsi Bali. Jurnal Magister Hukum Udayana(Udayana Master Law Journal), 8(2), 188-206. Google Scholar

Ulih, Adewisesa. (2016). Implementasi Peran Inspektorat Dalampengawasan Penyelenggaraan Pemerintah Daerah Kabupaten Agam Berdasarkan Peraturan Pemerintah Nomor 79 Tahun 2005 Tentang Pedoman Pembinaan Dan Pengawasan Penyelenggaraan Pemerintahan Daerah. Universitas Andalas. Google Scholar

Yuliana, Chintya Elva, Purnaweni, Hartuti, \& Rengga, Aloysius. (2015). Implementasi Undang-Undang Nomor 22 Tahun 2009 Tentang Lalu Lintas Dan Angkutan Jalan:(Khusus) Untuk Pengendara Sepeda Motor Di Kota Semarang. Journal Of Public Policy And Management Review, 4(2), 143-153. Google Scholar

\section{Copyright holder:}

Mico Juli Fikra, Gunawan Djajaputra (2021)

First publication right:

Syntax Literate: Jurnal Ilmiah Indonesia

This article is licensed under:

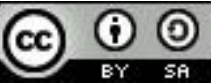

